\title{
Pregnancy per artificial insemination in lactating dairy cows subjected to 2 different intervals from presynchronization to initiation of Ovsynch protocol
}

\author{
M. G. Colazo, ${ }^{*}$ P. Ponce-Barajas, $\dagger$ and D. J. Ambrose ${ }^{*} \dagger^{1}$ \\ *Livestock Research Branch, Alberta Agriculture and Rural Development, Edmonton, AB, T6H 5T6, Canada \\ †Agricultural Food and Nutritional Science, University of Alberta, Edmonton, AB, T6G 2P5, Canada
}

\begin{abstract}
A protocol for presynchronization of ovarian status with 2 injections of $\mathrm{PGF}_{2 \alpha}$ given $14 \mathrm{~d}$ apart, with the last $\mathrm{PGF}_{2 \alpha}$ injection given 12 or $14 \mathrm{~d}$ before Ovsynch increases pregnancy per artificial insemination $(\mathrm{P} / \mathrm{AI})$ in dairy cows. We determined the efficacy of reducing the interval from the last $\mathrm{PGF}_{2 \alpha}$ injection $(500 \mu \mathrm{g}$ of cloprostenol) of presynchronization to initiation of Ovsynch on response to treatment and P/AI. Lactating dairy cows were assigned to an Ovsynch protocol, with the initial injection of $\mathrm{GnRH}$ given either 9 (PRE-9; $\mathrm{n}=135)$ or $12 \mathrm{~d}(\mathrm{PRE}-12 ; \mathrm{n}=135)$ after the second $\mathrm{PGF}_{2 \alpha}$ injection of presynchronization. The Ovsynch protocol consisted of 2 injections of $100 \mu \mathrm{g}$ of $\mathrm{GnRH}$ given $9 \mathrm{~d}$ apart and 1 injection of $\mathrm{PGF}_{2 \alpha}$ given $7 \mathrm{~d}$ after the initial $\mathrm{GnRH}$ injection, and cows were subjected to timed artificial insemination (TAI; $70 \pm 3.5 \mathrm{DIM}$ ) approximately $16 \mathrm{~h}$ after the second GnRH injection. Body condition score (1-5 scale) was recorded at TAI. Blood samples were taken for progesterone determination at the $\mathrm{PGF}_{2 \alpha}$ injection of Ovsynch, at TAI, and at $11 \mathrm{~d}$ after TAI. Ultrasonographic examinations were done in all cows at the second $\mathrm{PGF}_{2 \alpha}$ injection of presynchronization, initial $\mathrm{GnRH}$ injection, $\mathrm{PGF}_{2 \alpha}$ injection of Ovsynch, at TAI, and $24 \mathrm{~h}$ after TAI for cyclicity status and ovarian responses to treatments, and at 32 and $60 \mathrm{~d}$ after TAI for confirmation of pregnancy. Overall, 29 cows $(10.7 \%)$ were determined acyclic or cystic and excluded from the study. The percentage of cows responding to initial GnRH injection (62.2 vs. $61.5 \%$ ) did not differ between PRE-9 and PRE-12 but more cows in the PRE-9 group failed to respond to $\mathrm{PGF}_{2 \alpha}$ treatment of Ovsynch compared with PRE-12 (22.7 vs. $10.7 \%)$. Body condition score at TAI (2.9 \pm $0.02)$ and mean ovulatory follicle diameter $(16.4 \pm 0.2$ $\mathrm{mm}$ ) were not different between treatments. Overall P/ $\mathrm{AI}$ at $32 \mathrm{~d}$ was reduced in PRE-9 (33.6\%) compared with PRE-12 (44.3\%) but pregnancy losses (5.0 vs.
\end{abstract}

Received March 5, 2013.

Accepted August 9, 2013

${ }^{1}$ Corresponding author: divakar.ambrose@gov.ab.ca
$3.7 \%$ ) did not differ between treatments. Primiparous cows in the PRE-12 group had higher mean progesterone concentration $11 \mathrm{~d}$ after TAI and greater P/AI 32 after TAI than primiparous cows in the PRE-9 group $(6.4 \pm 0.5$ vs. $4.6 \pm 0.5 \mathrm{ng} / \mathrm{mL}$ and 55.8 vs. $30.0 \%$, respectively). In conclusion, reducing the interval from the last $\mathrm{PGF}_{2 \alpha}$ injection of the presynchronization treatment to initiation of Ovsynch (from 12 to $9 \mathrm{~d}$ ) did not affect ovulatory response to initial $\mathrm{GnRH}$ injection but reduced response to $\mathrm{PGF}_{2 \alpha}$ injection of Ovsynch and $\mathrm{P} / \mathrm{AI}$ at 32 and $60 \mathrm{~d}$ after TAI. The reduction in $\mathrm{P} / \mathrm{AI}$ was particularly evident in primiparous cows of the PRE-9 group.

Key words: presynchronization, Ovsynch, dairy cow, pregnancy per artificial insemination

\section{INTRODUCTION}

Protocols that synchronize ovulation (e.g., Ovsynch) to facilitate timed AI (TAI) are available management tools to improve reproductive performance in lactating dairy cows, as they increase the insemination risk (Pursley et al., 1997). However, Ovsynch does not improve conception rate mainly because the percentage of cows with a regressed corpus luteum (CL) and ovulating within 24 after TAI in Ovsynch-treated cows is only about $70 \%$ (Colazo et al., 2009, 2013). The stage of the estrous cycle at which Ovsynch protocol is initiated affects the synchronization rate (Vasconcelos et al., 1999; Moreira et al., 2000). To initiate the Ovsynch protocol in the most favorable stage of the estrous cycle, a presynchronization strategy that involves 2 injections of $\mathrm{PGF}_{2 \alpha}$, each given $12 \mathrm{~d}$ apart, has been developed (Moreira et al., 2001). Indeed, pregnancy per AI (P/AI) was increased when Ovsynch was initiated 12 (Moreira et al., 2001; El-Zarkouny et al., 2004) or $14 \mathrm{~d}$ (Navanukraw et al., 2004) after the last $\mathrm{PGF}_{2 \alpha}$ injection of the presynchronization protocol compared with Ovsynch, followed by TAI in randomly cycling lactating dairy cows.

It seems that synchronization and, eventually, pregnancy outcome to Ovsynch is influenced by the ovulatory response to initial GnRH injection (Vasconcelos et al., 1999; Bello et al., 2006; Galvão et al., 2007). Sev- 
eral factors may determine whether ovulation occurs in response to GnRH injection. The most important is perhaps the day of the estrous cycle (Martínez et al., 1999; Vasconcelos et al., 1999; Moreira et al., 2000; Bello et al., 2006). High progesterone concentrations suppressed pituitary release of $\mathrm{LH}$ and reduced the ovulatory response following the administration of $\mathrm{GnRH}$, indicating that circulating progesterone concentration can influence ovulation response to initial $\mathrm{GnRH}$ injection of Ovsynch, regardless of the stage of the estrous cycle (Colazo et al., 2008).

Vasconcelos et al. (1999) has shown that dairy cows at mid cycle (d 5 to 9 of the estrous cycle) have a greater probability of ovulating to $\mathrm{GnRH}$ injection than cows early (d 1 to 4 ) or late (d 10 to 16 ) in the cycle. Similarly, Galvão et al. (2007) has shown that initiation of a TAI protocol (i.e., Heatsynch) on approximately d 5 to 8 of the estrous cycle compared with d 8 to 11 increased the proportion of lactating dairy cows ovulating to initial GnRH injection (61.4 vs. 40.5\%). Moreover, Bello et al. (2006) reported that ovulation rate to initial GnRH injection in dairy cows treated 3,4 , or $5 \mathrm{~d}$ after induced ovulation were 56 , 67 , and $85 \%$, respectively. In 2 other studies with heifers, the ovulatory response to $\mathrm{GnRH}$ was optimized 3 to $5 \mathrm{~d}$ after ovulation (Martínez et al., 1999; Moreira et al., 2000). Therefore, controlling the interval from the second $\mathrm{PGF}_{2 \alpha}$ injection of presynchronization to initial GnRH injection, to have most cows between $\mathrm{d}$ 3 and 6 of the estrous cycle at initiation of Ovsynch, might increase ovulatory response to the first $\mathrm{GnRH}$ injection. We hypothesized that reducing the interval between the last $\mathrm{PGF}_{2 \alpha}$ injection of presynchronization and initiation of Ovsynch treatment from 12 to 9 $\mathrm{d}$ would further increase ovulatory response to initial GnRH and subsequent $\mathrm{P} / \mathrm{AI}$ in lactating dairy cows. Consequently, we compared ovarian responses, P/AI, and pregnancy loss in lactating dairy cows subjected to Ovsynch protocol initiated either 9 or $12 \mathrm{~d}$ after the second $\mathrm{PGF}_{2 \alpha}$ injection of the presynchronization protocol.

\section{MATERIALS AND METHODS}

All animal procedures were approved by the Animal Care and Use Committee for Livestock (University of Alberta, Edmonton, AB, Canada), and conducted in accordance with the guidelines of the Canadian Council on Animal Care (1993).

\section{Animals and Experimental Design}

This study was conducted with lactating Holstein cows from the Dairy Research Unit, University of Al- berta, with an annual rolling herd average of 10,370 kg of milk. Cows were housed in tie-stalls and had unrestricted access to water. They were fed individual rations once daily at approximately $0900 \mathrm{~h}$, allowed $2 \mathrm{~h}$ of exercise during the day, and milked twice daily between 0400 and $0600 \mathrm{~h}$ and 1530 and $1730 \mathrm{~h}$. Cows received a TMR formulated for lactating dairy cows according to NRC (2001) guidelines. Main ingredients were silage (barley and alfalfa), grain (barley or corn), hay (alfalfa or grass), and mineral supplements. Body condition score was determined before TAI by 1 individual using a scale of 1 (emaciated) to 5 (overconditioned; Edmonson et al., 1989).

Cows $(\mathrm{n}=270)$ were blocked by parity and date of calving, and randomly assigned, every week, to 1 of 2 treatments. All cows received their first and second $\mathrm{PGF}_{2 \alpha}(500 \mu \mathrm{g}$ of cloprostenol, Estrumate; ScheringPlough Animal Health, Pointe-Claire, QC, Canada) injections of the presynchronization protocol $14 \mathrm{~d}$ apart, with the first $\mathrm{PGF}_{2 \alpha}$ injection given approximately 5 wk after calving (Table 1). Cows were then subjected to an Ovsynch protocol (Pursley et al., 1997), initiated either 9 (PRE-9; $\mathrm{n}=135)$ or $12 \mathrm{~d}(\mathbf{P R E - 1 2} ; \mathrm{n}=135)$ after the last $\mathrm{PGF}_{2 \alpha}$ injection of presynchronization. Cows assigned to the PRE-9 group received their first $\mathrm{PGF}_{2 \alpha}$ injection of the presynchronization protocol $3 \mathrm{~d}$ after the first $\mathrm{PGF}_{2 \alpha}$ injection in cows assigned to the PRE-12 group. This staggered pattern of starting the presynchronization protocol was deliberately planned to ensure that TAI following the Ovsynch protocol occurred at the same DIM in both groups. The Ovsynch protocol consisted of $100 \mu \mathrm{g}$ of $\mathrm{GnRH}$ (gonadorelin acetate; Fertiline, Vétoquinol NA Inc., Lavaltrie, QC, Canada) on $\mathrm{d} 0$, followed $7 \mathrm{~d}$ later by a $\mathrm{PGF}_{2 \alpha}$ injection and $48 \mathrm{~h}$ later by a second GnRH injection, with TAI performed approximately $16 \mathrm{~h}$ after the second $\mathrm{GnRH}$ injection. All treatments were given i.m. and a trained technician performed all inseminations with frozenthawed commercial semen. Treatment protocols and activities during this study are illustrated in Figure 1.

\section{Ultrasonographic Examinations}

Transrectal ultrasonography (Aloka-500V scanner equipped with a $7.5-\mathrm{MHz}$ linear transducer; Aloka Co., Tokyo, Japan) was performed at second $\mathrm{PGF}_{2 \alpha}$ injection of presynchronization and during the Ovsynch protocol (e.g., at initial $\mathrm{GnRH}$ injection, at $\mathrm{PGF}_{2 \alpha}$ injection, at TAI, and $24 \mathrm{~h}$ later). The diameter and location of follicles and CL were recorded as previously described by Pierson and Ginther (1984). Cows with detectable luteal tissue at the second $\mathrm{PGF}_{2 \alpha}$ injection of presynchronization or first GnRH injection of Ovsynch, or both, were considered cyclic (Colazo et al., 2010). The 
Table 1. Days in milk, BCS, ovarian dynamics, and plasma progesterone at timed AI (TAI) of dairy cows according to the presynchronization treatment (results are shown as mean $\pm \mathrm{SE})^{1}$

\begin{tabular}{lcc}
\hline Item & PRE-9 & PRE-12 \\
\hline DIM & & \\
At first $\mathrm{PGF}_{2 \alpha}$ injection & $36.4 \pm 0.3^{\mathrm{a}}$ & $33.5 \pm 0.3^{\mathrm{b}}$ \\
At second $\mathrm{PGF}_{2 \alpha}$ injection & $50.4 \pm 0.3^{\mathrm{a}}$ & $47.5 \pm 0.3^{\mathrm{b}}$ \\
At TAI & $69.4 \pm 0.3$ & $69.5 \pm 0.3$ \\
Largest follicle diameter $^{2}(\mathrm{~mm})$ & $12.8 \pm 0.3^{\mathrm{a}}$ & $15.0 \pm 0.3^{\mathrm{b}}$ \\
Corpus luteum diameter $^{2}(\mathrm{~mm})$ & $19.5 \pm 0.5^{\mathrm{a}}$ & $21.9 \pm 0.5^{\mathrm{b}}$ \\
Plasma progesterone $(\mathrm{ng} / \mathrm{mL})$ at TAI & $0.6 \pm 0.09^{\mathrm{x}}$ & $0.4 \pm 0.09^{\mathrm{y}}$ \\
BCS at TAI & $2.9 \pm 0.02$ & $2.9 \pm 0.02$ \\
\hline
\end{tabular}

${ }^{a, b}$ Within a row, means without a common superscript differed $(P<0.01)$.

${ }^{\mathrm{x}, \mathrm{y}}$ Within a row, means without a common superscript differed $(P=0.09)$.

${ }^{1}$ Cows were subjected to an Ovsynch protocol initiated at either 9 (PRE-9) or 12 d (PRE-12) after the second $\mathrm{PGF}_{2 \alpha}$ injection of the presynchronization protocol.

${ }^{2}$ Determined based on ultrasonographic examinations at the initial GnRH injection of the Ovsynch protocol.

proportion of cows ovulating to initial GnRH injection of Ovsynch was determined retrospectively by recording the location, number, and size of follicles and CL on $\mathrm{d} 0$, and comparing these data to ovarian structures on d 7 (Colazo et al., 2009). The presence of a follicle $\geq 25 \mathrm{~mm}$ in diameter in the absence of luteal tissue at initiation of Ovsynch was defined as a cyst (Garverick, 1997). Ovulation to the second GnRH injection was confirmed by the disappearance of a large $(>10$ $\mathrm{mm}$ ) follicle that had been detected at the examination just before TAI. The type of ovulation (single or double) was recorded. Early ovulations were defined as those occurring between $\mathrm{PGF}_{2 \alpha}$ injection of Ovsynch and TAI. Maximal diameter of the ovulatory follicle was determined immediately before TAI. Cows whose ovarian status was synchronized were defined as those with plasma progesterone concentrations $<0.5 \mathrm{ng} / \mathrm{mL}$ at TAI and ovulating within $24 \mathrm{~h}$ after TAI. Pregnancy status and pregnancy loss was determined by transrectal ultrasonography at 32 and $60 \mathrm{~d}$ after TAI.

\section{Blood Collection and Hormone Assays}

Blood samples were collected by coccygeal venipuncture at $\mathrm{PGF}_{2 \alpha}$ injection of Ovsynch and at TAI in all cows, and $11 \mathrm{~d}$ after TAI in 186 cows (i.e., cows whose

PRE-9

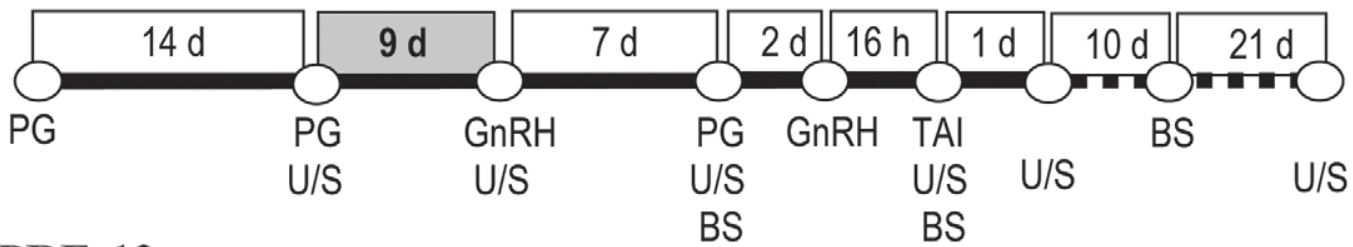

PRE-12

BS BS

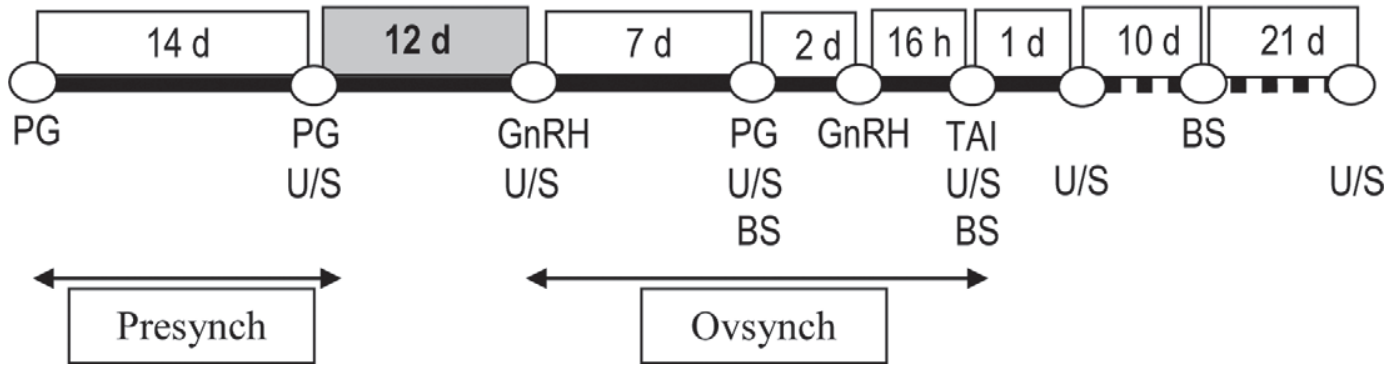

Figure 1. Diagram of activities and treatments during the study. All cows received 2 injections of $\mathrm{PGF}_{2 \alpha}(500 \mu \mathrm{g}$ of cloprostenol) $14 \mathrm{~d}$ apart (presynchronization protocol), with the second $\mathrm{PGF}_{2 \alpha}$ injection given either 9 (PRE-9) or $12 \mathrm{~d}$ (PRE-12) before initiation of a timed-AI (TAI) protocol (Ovsynch). The Ovsynch protocol consisted of $100 \mu \mathrm{g}$ of $\mathrm{GnRH}$, followed $7 \mathrm{~d}$ later by a $\mathrm{PGF}_{2 \alpha}$ injection, and $48 \mathrm{~h}$ later by a second GnRH injection, with TAI performed approximately $16 \mathrm{~h}$ after the second GnRH injection. Blood samples (BS) were taken for progesterone determination at the $\mathrm{PGF}_{2 \alpha}$ injection of Ovsynch, at TAI, and at $11 \mathrm{~d}$ after TAI. Ultrasonographic (U/S) examinations were performed at the second $\mathrm{PGF}_{2 \alpha}$ injection of presynchronization, initial $\mathrm{GnRH}$ injection, $\mathrm{PGF}_{2 \alpha}$ injection of Ovsynch, at TAI, and $24 \mathrm{~h}$ after TAI for response to treatment, and at $32 \mathrm{~h}$ after TAI for confirmation of pregnancy. Pregnant cows were re-examined by ultrasonography at $60 \mathrm{~d}$ after TAI. PG $=$ $\mathrm{PGF}_{2 \alpha}$. 
ovarian status was synchronized). Samples collected into evacuated tubes containing sodium heparin (Vacutainer; Becton Dickinson and Co., Franklin Lakes, $\mathrm{NJ}$ ) were immediately placed on ice and centrifuged within $3 \mathrm{~h}$ at $4^{\circ} \mathrm{C}$ for $20 \mathrm{~min}$ at $1,500 \times \mathrm{g}$. Plasma was separated and stored at $-20^{\circ} \mathrm{C}$ until progesterone concentrations were determined. Plasma concentrations of progesterone were determined using a solid-phase RIA (Coat-a-Count; Diagnostic Products Corp., Los Angeles, CA) with a minimum detection limit of $0.1 \mathrm{ng} / \mathrm{mL}$. The intraassay coefficients of variation were $6.3,10.9$, and $9.1 \%$ for low-, medium-, and high-progesterone reference samples, respectively. Luteolysis was confirmed when plasma progesterone concentrations were $>1 \mathrm{ng} /$ $\mathrm{mL}$ at $\mathrm{PGF}_{2 \alpha}$ injection and $<0.5 \mathrm{ng} / \mathrm{mL}$ at TAI (Martins et al., 2011).

\section{Statistical Analyses}

All data were analyzed using SAS (version 9.1 for Windows; SAS Institute Inc., Cary, NC). Binomial data were analyzed using generalized estimating equations (GEE) of the GENMOD procedure. Model specifications included a binomial distribution and a logit link function. For analysis of pregnancy status at 32 and 60 $\mathrm{d}$ after TAI, the model considered presynchronization treatments (PRE-9 or PRE-12), parity (primiparous or multiparous), ovulatory response to initial $\mathrm{GnRH}$ injection (yes or no), type of ovulation after second $\mathrm{GnRH}$ injection (single or double), and their interactions in all cyclic cows. Body condition score was included as a covariate. For analysis of ovarian responses to Ovsynch, the model considered presynchronization treatments, parity, and their interactions. Variables and interactions remaining in the final multivariable model at $P$ $<0.05$, based on the robust empirical standard errors produced by the GEE analysis, were considered statistically significant. The main-effects model was assessed for first-order interactions, where treatments remained in the model. Probability values $\leq 0.05$ were considered significant, and those between 0.051 and 0.10 were considered trends.

All single-measurement data (e.g., BCS, DIM at $\mathrm{PGF}_{2 \alpha}$ injections and initial GnRH injection, diameter of the largest follicle and CL at initial GnRH injection, plasma progesterone concentrations, and diameter of the ovulatory follicle) were analyzed using PROC MIXED. The effect of presynchronization treatments, parity, ovulatory response to initial $\mathrm{GnRH}$ injection, and their interactions on plasma progesterone and diameter of the ovulatory follicle were analyzed in 186 cows (i.e., cows whose ovarian status was synchronized). Type of ovulation (single or double) after second GnRH injection and pregnancy status was also included in the model when plasma progesterone concentrations after TAI were analyzed. Differences between means were tested by the PDIFF option and adjusted using the Tukey procedure.

The relationship between the diameter of the largest follicle at first $\mathrm{GnRH}$ injection and predicted probability of ovulation was computed using the PROC LOGISTIC of SAS. First-order (linear) and secondorder (quadratic) continuous effects of the explanatory variable were modeled.

\section{RESULTS}

Cows diagnosed acyclic $(\mathrm{n}=23 ; 8.5 \%)$ or with ovarian cyst $(\mathrm{n}=6 ; 2.2 \%)$ were not included in the statistical analyses. Therefore, data from 241 cows (50 primiparous and 69 multiparous in PRE-9, and 52 primiparous and 70 multiparous in PRE-12) were analyzed.

Days in milk at the first and second $\mathrm{PGF}_{2 \alpha}$ injection, DIM at TAI, largest follicle and CL diameter at initial GnRH injection, and BCS at TAI are shown in Table 1 (mean $\pm \mathrm{SE}$ ). Cows in the PRE-9 group received the $\mathrm{PGF}_{2 \alpha}$ injection of presynchronization at later DIM than cows in the PRE-12 group. However, DIM at TAI and BCS at TAI did not differ between presynchronization treatments. On average, cows in the PRE-9 group had smaller follicles and CL at initial GnRH injection than cows in the PRE-12 group (Table 1). Upon further analysis, 115 of $122(94.3 \%)$ cows in the PRE-12 group had a follicle $\geq 10 \mathrm{~mm}$ in diameter compared with 103 of $119(86.6 \%)$ cows in the PRE-9 group $(P<0.05)$. In addition, a quadratic relationship between largest follicle diameter at initial $\mathrm{GnRH}$ injection and predicted probability of ovulation was identified (Figure 2). Regression analysis indicated a maximum predicted probability of ovulation of 83.0 and 69.0 for PRE-9 and PRE-12 groups, respectively, when the diameter of the largest follicle was $16 \mathrm{~mm}$ (Figure 2).

Ovulatory response to initial GnRH injection was not affected by presynchronization treatments (Table 2 ), parity, or their interaction (Table 3). More cows in the PRE-9 group failed to respond to $\mathrm{PGF}_{2 \alpha}$ injection of Ovsynch compared with the PRE-12 group $(P<$ 0.01 ; Table 2). Consequently, the overall synchronization response to the Ovsynch protocol tended $(P=$ $0.06)$ to differ between presynchronization treatments (Table 2). Numerically more cows that ovulated to initial GnRH injection did not respond to $\mathrm{PGF}_{2 \alpha}$ injection in the PRE-9 group compared with the PRE-12 group $[P=0.2 ; 62.9 \%(17 / 27)$ vs. $46.2 \%(6 / 13)]$.

Overall, $\mathrm{P} / \mathrm{AI}$ at 32 and $60 \mathrm{~d}$ after TAI was greater $(P<0.01)$ in PRE-12 compared with PRE-9 cows but pregnancy losses did not differ between treatments (Figure 3). Four cows (4.3\%), all multiparous, lost the 


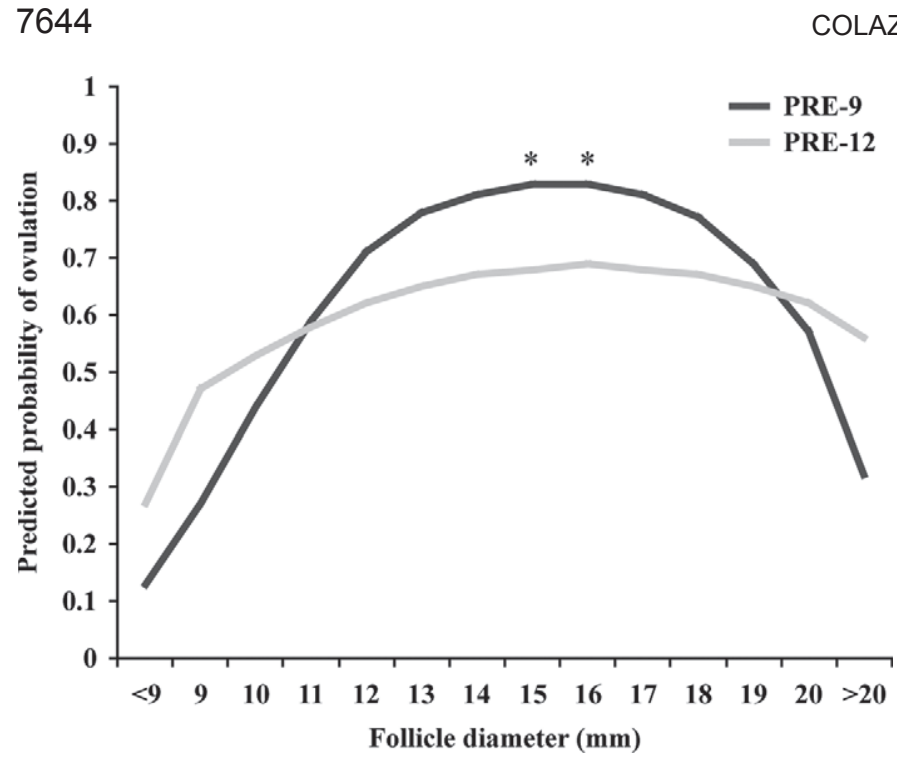

Figure 2. Relationship between diameter $(\mathrm{mm})$ of the largest follicle at first $\mathrm{GnRH}$ injection and predicted probability of ovulation in dairy cows. Cows were subjected to an Ovsynch protocol initiated at either 9 (PRE-9) or $12 \mathrm{~d}$ (PRE-12) after the second $\mathrm{PGF}_{2 \alpha}$ injection of the presynchronization protocol. Both regression lines show a quadratic effect $(P<0.01$ for PRE-9; $P=0.07$ for PRE-12). The maximum predicted probability of ovulation was 0.83 and 0.69 for PRE-9 and PRE-12, respectively, when the diameter of the largest follicle at the first $\mathrm{GnRH}$ injection was $16 \mathrm{~mm}$. The predicted probability of ovulation for follicle diameters of 15 and $16 \mathrm{~mm}$ was different $(P<0.05$; asterisks) between PRE-9 and PRE-12. pregnancy between 32 and $60 \mathrm{~d}$ after TAI. A 2-way interaction of treatment by parity on $\mathrm{P} / \mathrm{AI}$ was detected $(P<0.05$; Table 3$)$. Primiparous cows in the PRE- 12 group had greater $(P<0.05) \mathrm{P} / \mathrm{AI}$ at $32 \mathrm{~d}$ after TAI than primiparous cows in the PRE-9 group, but no differences were observed between multiparous cows (Table 3). However, primiparous cows in the PRE-12 group tended $(P=0.07)$ to have greater $\mathrm{P} / \mathrm{AI}$ than multiparous cows in both PRE-9 and PRE-12 groups.

Regardless of treatment, ovulatory response to initial GnRH injection and number of ovulations (single vs. double) after the second GnRH injection tended to affect $\mathrm{P} / \mathrm{AI}$ at 32 and $60 \mathrm{~d}$ after TAI. The $\mathrm{P} / \mathrm{AI}$ at 32 and $60 \mathrm{~d}$ after TAI tended $(P=0.09)$ to be higher in cows that ovulated after initial GnRH injection than in cows that did not ovulate (43.0 and 40.9 vs. 32.6 and $31.5 \%$, respectively). Albeit not statistically different, $\mathrm{P} / \mathrm{AI}$ was numerically lower $(P>0.05)$ in cows that ovulated in response to the first $\mathrm{GnRH}$ injection in the PRE-9 group (35.1\%; 26/74) compared with that in the PRE-12 group $(50.7 \%$; 38/75). Cows with double ovulations after the second $\mathrm{GnRH}$ injection also tended $(P$ $=0.07)$ to have greater $\mathrm{P} / \mathrm{AI}$ at 32 and $60 \mathrm{~d}$ after TAI than cows ovulating a single follicle $(65.2$ and $65.2 \%$ vs. 47.2 and $44.8 \%$, respectively).

The diameter of the ovulatory follicle (overall mean $16.4 \pm 0.2 \mathrm{~mm}$ ) was not different between treatments but a 2-way interaction of presynchronization treat-

Table 2. Effect of presynchronization treatment on ovarian responses of dairy cows subjected to the Ovsynch protocol $^{1}$

\begin{tabular}{|c|c|c|}
\hline Item & PRE-9 & PRE-12 \\
\hline Total no. of cows & 119 & 122 \\
\hline Ovulated after initial GnRH injection $^{2}[$ no. (\%)] & $74(62.2)$ & $75(61.5)$ \\
\hline Ovulated before $\mathrm{TAI}^{3}[$ no. $(\%)]$ & $5(4.2)$ & $6(4.9)$ \\
\hline Failed to respond to $\mathrm{PGF}_{2 \alpha}$ injection ${ }^{4}[$ no. (\%)] & $27(22.7)^{\mathrm{a}}$ & $13(10.7)^{\mathrm{b}}$ \\
\hline Failed to ovulate after $\mathrm{TAI}^{5}$ [no. $\left.(\%)\right]$ & $14(16.1)$ & $14(13.6)$ \\
\hline Double ovulation $^{6}[$ no. (\%) $]$ & $11(12.4)$ & $12(12.4)$ \\
\hline Overall synchronized $^{7}[$ no. $(\%)]$ & $73(61.3)^{x}$ & $89(73.0)^{y}$ \\
\hline
\end{tabular}

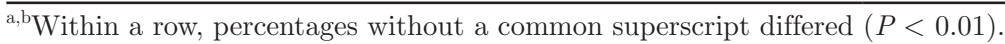

${ }^{\mathrm{x}, \mathrm{y}}$ Within a row, percentages without a common superscript differed $(P=0.06)$.

${ }^{1}$ Cows were subjected to an Ovsynch protocol initiated at either 9 (PRE-9) or $12 \mathrm{~d}$ (PRE-12) after the second $\mathrm{PGF}_{2 \alpha}$ injection of the presynchronization protocol.

${ }^{2}$ Determined based on ultrasonographic examinations at the initial $\mathrm{GnRH}$ injection and $\mathrm{PGF}_{2 \alpha}$ injection of the Ovsynch protocol.

${ }^{3}$ Percentage calculated as the number of cows ovulating between the $\mathrm{PGF}_{2 \alpha}$ injection of Ovsynch and timed AI (TAI) over the total number of cows. Determined based on ultrasonographic examinations at the PGF $\mathrm{F}_{2 \alpha}$ injection of the Ovsynch protocol and TAI.

${ }^{4}$ Percentage calculated as the number of cows with plasma progesterone concentrations $\geq 0.5 \mathrm{ng} / \mathrm{mL}$ at TAI over the total number of cows.

${ }^{5}$ Percentage calculated as the number of cows ovulating within $24 \mathrm{~h}$ after TAI over the total number of cows minus the cows that ovulated before TAI and those that did not respond to $\mathrm{PGF}_{2 \alpha}$ injection.

${ }^{6}$ Percentage calculated as the number of cows with double ovulation over the total number of cows whose ovarian status was synchronized.

${ }^{7}$ Percentage calculated as the number of cows responding to $\mathrm{PGF}_{2 \alpha}$ injection and ovulating within $24 \mathrm{~h}$ after TAI over the total number of cows. 


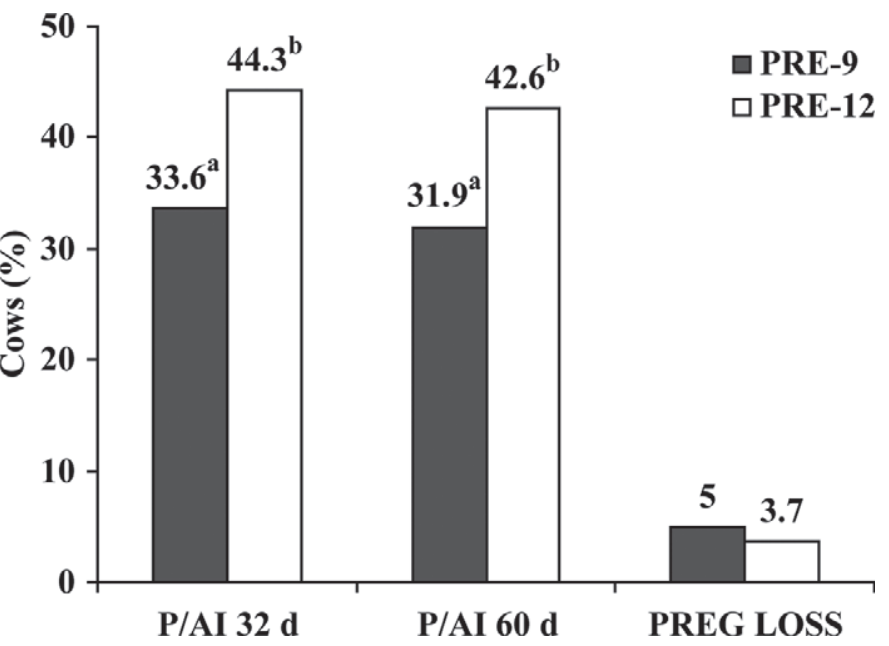

Figure 3. Pregnancy per AI (P/AI) at 32 and $60 \mathrm{~d}$ after timed AI (TAI) and pregnancy losses in lactating dairy cows subjected to an Ovsynch protocol initiated at either 9 (PRE-9) or 12 d (PRE-12) after the second $\mathrm{PGF}_{2 \alpha}$ injection of the presynchronization protocol. The PRE-9 group resulted in reduced P/AI at 32 and $60 \mathrm{~d}$ after TAI compared with the PRE-12 group. Pregnancy loss did not differ between groups. Percentages without a common letter ( $\mathrm{a}$ and $\mathrm{b})$ differed $(P<$ 0.01). PREG = pregnancy.

ment by parity on diameter of ovulatory follicle was detected (Table 3). Multiparous cows in the PRE-9 group and primiparous cows in the PRE-12 group had larger $(P<0.05)$ ovulatory follicles than multiparous cows in the PRE-12 group. Ovulatory follicle diameter in primiparous cows in the PRE-9 group did not differ from that in the other 3 subgroups (Table 3 ).

Plasma progesterone concentration at $\mathrm{PGF}_{2 \alpha}$ injection of Ovsynch did not differ between treatments $(P$ $>0.05 ; 6.0 \pm 0.3$ vs. $6.4 \pm 0.3 \mathrm{ng} / \mathrm{mL}$ for PRE-9 and PRE-12, respectively). Circulating progesterone at $\mathrm{PGF}_{2 \alpha}$ injection of Ovsynch was only affected by ovulatory response to initial GnRH injection. Regardless of presynchronization treatment, cows that ovulated after first GnRH injection had greater $(P<0.05)$ progesterone concentration than cows that did not ovulate (6.7 \pm 0.3 vs. $5.7 \pm 0.3 \mathrm{ng} / \mathrm{mL}$ ).

Plasma progesterone concentrations at TAI differed between presynchronization treatments (Table 1), but it could neither be attributed to ovulatory response to initial GnRH injection nor to any interaction between presynchronization treatments and ovulatory response to initial GnRH injection.

Concentration of plasma progesterone $11 \mathrm{~d}$ after TAI was greater $(P<0.01)$ in PRE-12 cows compared with PRE-9 cows $(5.9 \pm 0.3$ vs. $4.8 \pm 0.4 \mathrm{ng} / \mathrm{mL})$. The number of cows with plasma progesterone concentration $<1$ $\mathrm{ng} / \mathrm{mL} 11 \mathrm{~d}$ after TAI was 2 and 5 for PRE-12 and PRE-9, respectively. Plasma progesterone concentration $11 \mathrm{~d}$ after TAI was also affected $(P<0.05)$ by the 
interaction of presynchronization treatment and parity (Table 3). Primiparous cows in the PRE-12 group had greater $(P<0.05)$ plasma progesterone concentrations compared with primiparous and multiparous cows in the PRE-9 group. The plasma progesterone concentration in multiparous cows in the PRE-12 group did not differ from that in the other 3 subgroups (Table 3 ).

\section{DISCUSSION}

This study was designed to compare ovarian responses and $\mathrm{P} / \mathrm{AI}$ in lactating dairy cows subjected to Ovsynch protocol initiated either 9 or $12 \mathrm{~d}$ after the second $\mathrm{PGF}_{2 \alpha}$ injection of the presynchronization protocol. Ovulatory response to first $\mathrm{GnRH}$ injection did not differ between presynchronization protocols. However, more cows subjected to an Ovsynch protocol initiated $9 \mathrm{~d}$ following the last $\mathrm{PGF}_{2 \alpha}$ injection of presynchronization group failed to respond to $\mathrm{PGF}_{2 \alpha}$ injection of Ovsynch and had lower P/AI compared with cows subjected to an Ovsynch protocol initiated $12 \mathrm{~d}$ following the last $\mathrm{PGF}_{2 \alpha}$ injection of presynchronization.

The presynchronization protocol with 2 injections of $\mathrm{PGF}_{2 \alpha}$ given $12 \mathrm{~d}$ apart has been developed as a strategy to increase the proportion of cows in mid cycle at initiation of an Ovsynch protocol, which improved the overall response to the protocol and subsequently increased P/ AI (Moreira et al., 2001). In 2 separate studies, the initiation of an Ovsynch protocol in lactating dairy cows $12 \mathrm{~d}$ after last $\mathrm{PGF}_{2 \alpha}$ injection of presynchronization resulted in higher $\mathrm{P} / \mathrm{AI}$ of 49.8 versus $36.5 \%$ (Moreira et al., 2001) and 46.8 versus $37.5 \%$ (El-Zarkouny et al., 2004) than in cows subjected to Ovsynch without presynchronization. A similar increase in $\mathrm{P} / \mathrm{AI}$ was reported by Navanukraw et al. (2004) in Ovsynch-treated cows when the protocol was initiated $14 \mathrm{~d}$ after presynchronization compared with Ovsynch-treated cows without presynchronization (49.6 vs. $37.3 \%$ ).

The dairy industry has adopted the presynchronization/Ovsynch protocol, with the first GnRH injection of Ovsynch commonly given $14 \mathrm{~d}$ after the last $\mathrm{PGF}_{2 \mathrm{\alpha}}$ injection of presynchronization so that treatments are conveniently administered on the same days of the week. As many cows would come into estrus and ovulate spontaneously 3 to $6 \mathrm{~d}$ following the second $\mathrm{PGF}_{2 \mathrm{\alpha}}$ injection of the presynchronization protocol (Chebel et al., 2006), they are more likely to have lower circulating progesterone and an active, LH-responsive, first-wave dominant follicle at an interval shorter than $14 \mathrm{~d}$ after the second $\mathrm{PGF}_{2 \alpha}$ injection. Thus, a shorter interval from presynchronization to initial $\mathrm{GnRH}$ injection of Ovsynch was expected to further optimize the ovarian synchrony. In this regard, Galvão et al. (2007) reported that reducing the interval between last $\mathrm{PGF}_{2 \alpha}$ injection of presynchronization and initiation of a TAI protocol by $3 \mathrm{~d}$ ( 11 vs. $14 \mathrm{~d})$ increased the proportion of lactating dairy cows ovulating to initial GnRH injection (61.4 vs. $40.5 \%$ ). In the present study, shortening the interval from 12 to $9 \mathrm{~d}$ between the last $\mathrm{PGF}_{2 \alpha}$ injection of presynchronization and initiation of Ovsynch did not significantly increase ovulatory response to the initial GnRH injection. Therefore, our findings did not support the hypothesis that reducing the interval from last $\mathrm{PGF}_{2 \alpha}$ injection of presynchronization to initiation of Ovsynch would increase the chances for ovulation. The diameter of the largest follicle present at initial GnRH injection of Ovsynch may have limited the ovulatory response in PRE-9 cows, as the overall proportion of cows with a follicle $\geq 10 \mathrm{~mm}$ was lower compared with cows in PRE-12 group. However, the responsiveness of follicles to LH was greater in PRE-9 cows, as the predicted probability of ovulation was higher in the PRE-9 group than that in the PRE-12 for cows with ovaries containing follicles of $15 / 16 \mathrm{~mm}$ in diameter.

Bello et al. (2006) have indicated that pregnancy outcome to Ovsynch is highly associated with the ovulatory response to initial GnRH injection. Because reducing the interval from presynchronization to initiation of Heatsynch from 14 to $11 \mathrm{~d}$ also increased $\mathrm{P} / \mathrm{AI}$, it has been suggested that the improvement of $\mathrm{P} / \mathrm{AI}$ was likely the consequence of increased ovulatory response to initial GnRH injection (Galvão et al.; 2007). Although cows subjected to an Ovsynch protocol initiated $9 \mathrm{~d}$ after the last $\mathrm{PGF}_{2 \alpha}$ injection of presynchronization group had lower P/AI compared with cows subjected to an Ovsynch protocol initiated $12 \mathrm{~d}$ after the last $\mathrm{PGF}_{2 \alpha}$ injection of presynchronization, in our study, the differences in P/AI cannot be attributed to the ovulatory response to initial $\mathrm{GnRH}$ injection of Ovsynch. We have previously reported that ovulation in response to first GnRH injection of Ovsynch is not critical for conception in cyclic cows, whereas substantial reduction in $\mathrm{P} / \mathrm{AI}$ occurs in acyclic cows that do not ovulate to the initial $\mathrm{GnRH}$ injection (Colazo et al., 2013). It is noteworthy that in the present study all cows were cycling. Shortening the interval from 12 to 9 $\mathrm{d}$ between the last $\mathrm{PGF}_{2 \alpha}$ injection of presynchronization and initiation of Ovsynch tended to reduce the overall proportion of cows responding to Ovsynch protocol because more cows in the PRE-9 failed to undergo complete luteolysis.

It is well known that CL sensitivity to exogenous $\mathrm{PGF}_{2 \alpha}$ changes through the estrous cycle (Momont and Seguin, 1982). The early CL is nonresponsive to a single injection of $\mathrm{PGF}_{2 \alpha}$ and its analogs but sensitivity increases toward the end of the luteal phase, when responsiveness is at its maximum. It is plausible that 
cows in the PRE-12 group had a more sensitive CL at the time of $\mathrm{PGF}_{2 \alpha}$ injection, as they were more likely to have been in late diestrus. Conversely, cows in the PRE-9 group were in early or mid diestrus at the time of $\mathrm{PGF}_{2 \alpha}$ injection. Albeit not statistically significant, cows that ovulated to initial GnRH injection in the PRE-9 group were more likely to fail to respond to $\mathrm{PGF}_{2 \alpha}$ injection. Incomplete luteolysis following administration of $\mathrm{PGF}_{2 \alpha}$ in the Ovsynch protocol has been associated with initiation of the Ovsynch protocol during late diestrus. In cattle where the Ovsynch protocol was initiated on d 18 of the estrous cycle, even though the response to initial GnRH injection was quite high, luteolytic response to $\mathrm{PGF}_{2 \alpha}$ injection was poor (Moreira et al. 2000). The higher proportion of incomplete luteolysis in the PRE-9 group possibly contributed to reduced pregnancy rates in that group.

Ovulatory response to the initial GnRH injection was not directly associated with improved $\mathrm{P} / \mathrm{AI}$ among cows subjected to the PRE-9 treatment, as a numerically lower proportion of cows that ovulated after $\mathrm{GnRH}$ injection became pregnant. It is also possible that the largest subordinate follicle became dominant following ovulation of the dominant follicle present at the time of first GnRH injection. In a previous study, ablation of 1,2 , or 3 of the largest follicles at or shortly after the beginning of deviation was followed by the establishment of dominance by the largest retained follicle in most the heifers (Ginther et al., 2001). Although we cannot directly compare a follicular ablation to that of a GnRH-induced ovulation, we speculate that the gonadotropin surge following $\mathrm{GnRH}$ injection might have rescued a subordinate follicle from regression in some PRE-9 cows that ovulated in response to the first GnRH injection. Consequently, these cows likely ovulated an aged oocyte of compromised fertility from a rescued subordinate follicle, following the second $\mathrm{GnRH}$ injection, resulting in lower P/AI. Conversely, in most of the PRE-12 cows, a new follicular wave possibly emerged during Ovsynch, regardless of ovulatory response to first GnRH injection, as they were more likely to be in mid diestrus at initial GnRH injection, allowing for the spontaneous emergence of a new dominant follicle.

Based on the present findings and that of previous studies (Moreira et al., 2001; El-Zarkouny et al., 2004; Galvão et al., 2007), it seems that an interval of 11 or $12 \mathrm{~d}$ from second $\mathrm{PGF}_{2 \alpha}$ injection of presynchronization to initiation of Ovsynch would be the most appropriate to optimize P/AI. The 12-d interval from presynchronization to initiation of Ovsynch was particularly beneficial to primiparous cows. It remains unclear why primiparous cows subjected to the PRE-12 protocol had greater $\mathrm{P} / \mathrm{AI}$ than primiparous cows subjected to the PRE-9 protocol. Neither the mean diameter of ovu- latory follicle nor plasma progesterone concentrations at $\mathrm{PGF}_{2 \alpha}$ injection of Ovsynch was attributable to the difference in $\mathrm{P} / \mathrm{AI}$. Although primiparous cows in the PRE-12 had greater plasma progesterone concentrations $11 \mathrm{~d}$ after TAI, it is unknown whether that was the cause or the effect of the improved P/AI.

\section{CONCLUSIONS}

Reducing the interval from last $\mathrm{PGF}_{2 \alpha}$ injection of presynchronization to initiation of Ovsynch, from 12 to $9 \mathrm{~d}$, did not affect ovulatory response to initial GnRH injection but reduced response to $\mathrm{PGF}_{2 \alpha}$ injection of Ovsynch and $\mathrm{P} / \mathrm{AI}$ at 32 and $60 \mathrm{~d}$ after TAI. The reduction in $\mathrm{P} / \mathrm{AI}$ was particularly evident in primiparous cows of the PRE-9 group.

\section{ACKNOWLEDGMENTS}

This research was supported by Alberta Agriculture and Rural Development (Livestock Research Branch, Edmonton, AB, Canada), Agriculture and Food Council of Alberta (Edmonton, AB, Canada), Alberta Innovates-Bio Solutions (Edmonton, AB, Canada), Alberta Livestock and Meat Agency (Edmonton, AB, Canada), and Alberta Milk (Edmonton, AB, Canada). Product donations by Schering-Plough Animal Health (Pointe-Claire, QC, Canada; Estrumate) and Vétoquinol Canada Inc. (Lavaltrie, QC; Fertiline) are also acknowledged. The authors thank Jamie Kratchkowski (Livestock Research Branch, Edmonton, AB, Canada) for her technical support and the staff of the Dairy Research Technology Centre, for their cooperation and care and management of the cattle.

\section{REFERENCES}

Bello, N. M., J. P. Steibel, and J. R. Pursley. 2006. Optimizing ovulation to first $\mathrm{GnRH}$ improved outcomes to each hormonal injection of Ovsynch in lactating dairy cows. J. Dairy Sci. 89:3413-3424.

Canadian Council on Animal Care. 1993. Guide to the care and use of experimental animals. Vol. 1, 2nd ed. Canadian Council on Animal Care, Ottawa, ON. Accessed Jan. 27, 2013. http://www.ccac.ca/ Documents/Standards/Guidelines/Experimental_Animals_Vol1. pdf.

Chebel, R. C., J. E. P. Santos, R. L. A. Cerri, H. M. Rutigliano, and R. G. S. Bruno. 2006. Reproduction in dairy cows following progesterone insert presynchronization and resynchronization protocols. J. Dairy Sci. 89:4205-4219.

Colazo, M. G., D. J. Ambrose, and J. P. Kastelic. 2010. Practical uses for transrectal ultrasonography in reproductive management of cattle. Pages 146-156 in Proc. World Buiatrics Congress. Chilean Buiatrics Society, Santiago, Chile.

Colazo, M. G., A. Dourey, R. Rajamahendran, and D. J. Ambrose. 2013. Progesterone supplementation before timed AI increased ovulation synchrony and pregnancy per AI, and supplementation after timed AI reduced pregnancy losses in lactating dairy cows. Theriogenology 79:833-841.

Colazo, M. G., M. B. Gordon, R. Rajamahendran, R. J. Mapletoft, and D. J. Ambrose. 2009. Pregnancy rates to timed artificial insemina- 
tion in dairy cows treated with gonadotropin-releasing hormone or porcine luteinizing hormone. Theriogenology 72:262-270.

Colazo, M. G., J. P. Kastelic, H. Davis, M. D. Rutledge, M. F. Martínez, J. A. Small, and R. J. Mapletoft. 2008. Effects of plasma progesterone concentrations on LH release and ovulation in beef cattle given GnRH. Domest. Anim. Endocrinol. 34:109-117.

Edmonson, A. J., I. J. Lean, L. D. Weaver, T. Farver, and G. Webster. 1989. A body condition scoring chart for Holstein dairy cows. J. Dairy Sci. 72:68-78.

El-Zarkouny, S. Z., J. A. Cartmill, B. A. Hensley, and J. S. Stevenson. 2004. Pregnancy in dairy cows after synchronized ovulation regimens with or without presynchronization and progesterone. J. Dairy Sci. 87:1024-1037.

Galvão, K. N., M. F. Sá Filho, and J. E. P. Santos. 2007. Reducing the interval from presynchronization to initiation of timed artificial insemination improves fertility in dairy cows. J. Dairy Sci. 90:4212-4218.

Garverick, H. A. 1997. Ovarian follicular cysts in dairy cows. J. Dairy Sci. 80:995-1004.

Ginther, O. J., D. R. Bergfelt, M. A. Beg, and K. Kot. 2001. Follicle selection in cattle: Relationship among growth rate, diameter ranking, and capacity for dominance. Biol. Reprod. 65:345-350.

Martínez, M. F., G. P. Adams, D. R. Bergfelt, J. P. Kastelic, and R. J. Mapletoft. 1999. Effect of LH or GnRH on the dominant follicle of the first follicular wave in beef heifers. Anim. Reprod. Sci. 57:23-33.

Martins, J. P. N., R. K. Policelli, L. M. Neuder, W. Raphael, and J. R. Pursley. 2011. Effects of cloprostenol sodium at final prostaglandin $\mathrm{F}_{2 \alpha}$ of Ovsynch on complete luteolysis and pregnancy per artificial insemination in lactating dairy cows. J. Dairy Sci. 94:2815-2824.
Momont, H. W., and B. E. Seguin. 1982. Temporal factors affecting the response to prostaglandin $\mathrm{F}_{2 \alpha}$ products in dairy cattle. Pages 166-167 in Proc. Annu. Conf. Soc. Theriogenology. Society for Theriogenology, Milwaukee, WI.

Moreira, F., R. L. de la Sota, T. Diaz, and W. W. Thatcher. 2000. Effect of day of the estrous cycle at the initiation of a timed artificial insemination protocol on reproductive responses in dairy heifers. J. Anim. Sci. 78:1568-1576.

Moreira, F., C. Orlandi, C. A. Risco, R. Mattos, F. Lopes, and W. W. Thatcher. 2001. Effects of presynchronization and bovine somatotropin on pregnancy rates to a timed artificial insemination protocol in lactating dairy cows. J. Dairy Sci. 84:1646-1659.

NRC. 2001. Nutrient Requirements of Dairy Cattle. 7th rev. ed. Natl. Acad. Press, Washington, DC.

Navanukraw, C., D. A. Redmer, L. P. Reynolds, J. D. Kirsch, A. T. Grazul-Bilska, and P. M. Fricke. 2004. A modified presynchronization protocol improves fertility to timed artificial insemination in lactating dairy cows. J. Dairy Sci. 87:1551-1557.

Pierson, R. A., and O. J. Ginther. 1984. Ultrasonography of the bovine ovary. Theriogenology 21:495-504.

Pursley, J. R., M. C. Wiltbank, J. S. Stevenson, J. S. Ottobre, H. A. Garverick, and L. L. Anderson. 1997. Pregnancy rates per artificial insemination for cows and heifers inseminated at a synchronized ovulation or synchronized estrus. J. Dairy Sci. 80:295-300.

Vasconcelos, J. L. M., R. W. Silcox, G. J. M. Rosa, J. R. Pursley, and M. C. Wiltbank. 1999. Synchronization rate, size of the ovulatory follicle, and pregnancy rate after synchronization of ovulation beginning on different days of the estrous cycle in lactating dairy cows. Theriogenology 52:1067-1078. 